\title{
KONSEP KONTRAK PINTAR DAN POTENSINYA TERHADAP TRANSAKSI PEMBIAYAAN BERASASKAN TAWARRUQ*
}

\section{Smart Contract Concept and Its Potential to Tawarruq-Based Financing Transactions}

\author{
Muhammad Izzul Syahmi Zulkepli** \\ Mohammad Taqiuddin Mohamad*** \\ Saaidal Razalli Azzuhri****
}

\begin{abstract}
A contract is an important concept to enable a transaction without jeopardizing the rights and security of the transaction's parties. Its implementation
\end{abstract}

* Penulisan artikel ini adalah sebahagian daripada hasil penyelidikan geran yang ditaja Kementerian Pengajian Tinggi di bawah geran FRGS/1/2020/SS01/UM/03/01, "Pembentukan Parameter Pengurusan Risiko Kontrak Pintar Syariah (Shariah Smart Contract) Berasaskan Teknologi Blockchain dalam Penawaran Produk Kewangan Islam Malaysia."

** PhD Candidate, Department of Shariah and Economics, Academy of Islamic Studies, University of Malaya, 50603, Kuala Lumpur. izzulsyahmi95@gmail.com (Corresponding Author)

*** Senior Lecturer, Department of Shariah and Economics, Academy of Islamic Studies, University of Malaya, 50603, Kuala Lumpur. m.taqiuddin@um.edu.my

**** Senior Lecturer, Department of Computer System and Technology, Faculty of Computer Science and Information Technology, University of Malaya, 50603, Kuala Lumpur. saaidal@um.edu.my 
varies either through traditional or modern methods. To date, the smart contract gains attention among industry players and academicians. It is a modern technological innovation that can execute a contract by utilizing a blockchain network. In particular, the researchers view that smart contracts can be adapted in products offering based on various Shariah contracts in Islamic banking institutions, such as financing products based on the tawarruq contract. Nevertheless, it requires detailed research in terms of concept and structure to measure its potential to integrate with Islamic banking operations. Therefore, this study will examine the smart contract concept as well as identify its advantages for Islamic banking institutions' operations, particularly in tawarruqbased financing products. A qualitative approach based on library studies concerning relevant documents and literature are implemented to achieve these objectives. The collected data were then analyzed using descriptive content analysis methods. The results found that the smart contract is a contract innovation based on blockchain technology that can implement tawarruq-based financing products terms automatically, decentralized, and distributed manner. Thus, its thorough implementation can reduce the risk of faults in transactions and potentially ensure the transparency of transactions' is well-preserved. However, further research on the risks associated with this technology, especially Shariah risks, needs to be clarified before being fully integrated into Islamic banking operations.

Keywords: Decentralized Application (Dapp), Decentralized Finance (Defi), Commodity Murabahah, Industrial Revolution 4.0, Islamic Financial Institutions. 


\section{PENDAHULUAN}

Kontrak pintar dan blok rantai adalah sebahagian inovasi teknologi moden hasil dari revolusi industri 4.0 selain dari beberapa inovasi lain seperti data raya (big data) dan kecerdasan buatan (artificial intelligence) yang mampu menjadikan aktiviti harian manusia lebih mudah dan pantas. ${ }^{1}$ Inovasi rangkaian blok rantai berkembang sehingga boleh melaksanakan kod kontrak pintar. Hal ini menyebabkan sesuatu transaksi menggunakan kod kontrak pintar dapat dilaksanakan secara automatik, desentralisasi dan teredar (distributed). Disebabkan itu, potensi teknologi ini mula diteroka oleh pelbagai sektor dan perkhidmatan, umpamanya sektor halal, ${ }^{2}$ zakat, ${ }^{3}$ wakaf, ${ }^{4}$ perbankan Islam ${ }^{5}$ dan takaful. ${ }^{6}$

Khususnya dalam sektor perbankan di Malaysia, terdapat pelbagai usaha mengintegrasi teknologi kontrak pintar dalam operasi penawaran produk dan perkhidmatan institusi masing-

1 Siti Rohaya et al., "Artificial Intelligence, Smart contract and Islamic Finance," Asian Social Journal 14, no. 2 (2018), 145-154.

2 Marco Tieman dan Mohd Ridzuan, "Leveraging Blockchain Technology for Halal Supply Chains," Islam and Civilisation Renewal 8, no. 40 (2017), 547-550.

3 Farrukh Habib dan Moutaz Abojeib, " Realities and Innovation Challenges Potential Application of FinTech for Islamic Social Financing Institutions," (makalah: $13^{\text {th }}$ International Shariah Scholars Forum, Kuala Lumpur, 1-2 Oktober 2018), 1-19.

4 Magda Ismail danAishath Muneeza, "Integrating WaqfCrowdfunding into The Blockchain," dalam Fintech in Islamic Finance: Theory and Practise (New York: Routledge, 2019), 265-279.

5 Aishath Muneeza \& Zakariya Mustapha, "Blockchain and Its Shariah Compliant Structure," dalam Halal Cryptocurrency Management (Cham: Palgrave Macmillan, 2019), 69-106; Farrukh Habib, "Smart Contracts for Islamic Financial Transaction," dalam IFIKR DIGEST 11, (IFIKR, Kuala Lumpur, 2019), 10-15; Siti Rohaya et al., "Artificial Intelligence, Smart contract and Islamic Finance," Asian Social Journal 14, no. 2 (2018), 145-154; Richard-Marc, Berthe Lambert dan Nida Khan, "Blockchain Technology-Arsenal for a Shariah-Compliant Financial Ecosystem," Journal of Business and Economics (2017), 1-11.

6 Mohammad Abdeen et al., Employing Takaful Islamic Banking Through State of The Art Blockchain: A Case Study," IJACSA 10, no. 12 (2019), 648-653. 
masing. Timbalan gabenor Bank Negara Malaysia dalam ucapannya di satu konvensyen kewangan digital pada tahun 2018 menyatakan terdapat sembilan institusi perbankan yang mula memanfaatkan teknologi kontrak pintar dan blok rantai dalam penawaran produk pembiayaan perdagangan, ${ }^{7}$ antaranya institusi perbankan HSBC. ${ }^{8}$ Dalam pada itu, institusi Finterra menyediakan servis waqf dengan menggunakan platform kontrak pintar dan blok rantai. ${ }^{9}$

Selain itu, institusi kewangan Bursa Malaysia mula menggunakan teknologi ini dalammenawarkan servis institusinya. ${ }^{10}$ Manakala institusi Bank Islam Malaysia Berhad (BIMB) dan Hong Leong masih di peringkat kajian dalam membangunkan perbankan digital yang berteraskan teknologi revolusi 4.0 untuk meraih perhatian pelanggan pada masa hadapan. ${ }^{11}$ Dalam pada itu, badan kawal selia Bank Negara Malaysia menerbitkan Kerangka

7 Jessica Chew Cheng Lian, "Deputy Governor's Opening Address at the Asian Banker Digital Finance Convention 2018," laman sesawang $B N M$, dicapai pada 2 Februari 2021, https://www.bnm. gov.my/-/deputy-governor-s-opening-address-at-the-asian-bankerdigital-finance-convention-2018.

8 HSBC, "HSBC Succesfully Pilots Malaysia's First Letter of Credit Transaction on The Blockchain," laman sesawang Fintechnews.my, dicapai pada 2 Februari 2021, Fintechhttps://fintechnews.my/21774/ blockchain/hsbc-pilots-blockchain-letter-of-credit-transactionbetween-malaysia-and-singapore/.

9 Finterra, "About us," laman sesawang Finterra, dicapai pada 5 Mei 2021, https://finterra.org/.

10 Bursa Malaysia, "Securities Borrowing And Lending: The Blockchain Path To Building Operational Efficiencies," laman sesawang BM, dicapai pada 7 Disember 2020, https://www.bursamalaysia.com/cn/ about_bursa/media_centre/securities-borrowing-and-lending-theblockchain-path-to- building- operational-efficiencies

11 The Star, "Bank Islam to Offer Digital Products," laman sesawang The Star, dicapai pada 7 Disember 2020, https://www.thestar.com. my/business/business-news/2020/02/18/bank-islam-to-offer-digitalproducts ; HLIB, "Digital at the Core," laman sesawang HLIB, dicapai pada 2 Februari 2021https://www.hlisb.com.my/content/ $\mathrm{dam} / \mathrm{hlisb} / \mathrm{my} / \mathrm{docs} / \mathrm{pdf} /$ About-Us/Investor-Relations/AnnualQuarterly-Reports/2018/annual-report/hlisb-annual-report-2018. pdf. 
Peraturan Teknologi Kewangan Sandbox pada tahun $2016^{12}$ dan Rangka Kerja Perlesenan untuk Bank Digital pada hujung tahun 2020. ${ }^{13}$ Usaha ini bertujuan meneliti risiko-risiko yang terkait dengan operasi digital dan teknologi moden di samping menyokong arus perkembangan teknologi yang pesat.

Di samping itu, terdapat beberapa pengkaji seperti Aishath Muneeza (2019), ${ }^{14}$ Farukh Habib (2019), ${ }^{15}$ Hussein Elasrag $(2019)^{16}$ dan Siti Rohaya (2018) ${ }^{17}$ mencadangkan kontrak pintar diadaptasi ke dalam operasi penawaran produk perbankan Islam. Ini kerana mereka berpandangan produk-produk perbankan Islam yang berasaskan kontrak Syariah seperti tawarruq, mushārakah dan mud̄ārabah, seperti produk pembiayaan berpotensi dijalankan melalui kontrak pintar dan blok rantai.

Hal ini jelas menunjukkan perkembangan aplikasi teknologi seperti kontrak pintar dan kajian berkaitannya semakin berkembang pesat. Gesaan terhadap penggunaan teknologi kewangan dalam operasi kewangan ini ditambah lagi dengan penularan wabak pandemik Covid- $19^{18}$ yang diibaratkan sebagai batu loncatan kepada perubahan tingkah laku pelanggan dalam mendapatkan perkhidmatan perbankan dan tindak balas pihak

12 BNM, "Financial Technology Regulatory Sandbox Framework," laman sesawang $B N M$, dicapai pada 2 Februari 2021, https://www. bnm.gov.my/index.php?ch=57\&pg=137\&ac=533\&bb=file.

13 BNM, "Licensing Framework for Digital Banks," laman sesawang BNM, dicapai pada 2 Februari 2021 https://www.bnm.gov.my/ documents/20124/938039/20201231_Licensing+Framework+for+ Digital+Banks.pdf.

14 Aishath Muneeza \& Zakariya Mustapha, "Blockchain and Its Shariah Compliant Structure," dalam Halal Cryptocurrency Management (Cham: Palgrave Macmillan, 2019).

15 Farrukh Habib, "Smart Contracts for Islamic Financial Transaction," dalam IFIKR DIGEST 11, (IFIKR, Kuala Lumpur, 2019), 10-15.

16 Hussein Elasrag, "Blockchains for Islamic Finance: Obstacles \& Challenges," MPRA (2019), 1-32.

17 Siti Rohaya et al., "Artificial Intelligence, Smart contract and Islamic Finance," Asian Social Journal 14, no. 2 (2018), 145-154.

18 Crowe, "Blockchain \& COVID-19: An Ongoing Conversation," laman sesawang Crowe, dicapai pada 14 April 2020, https://www. crowe.com/sg/insights/blockchain-and-covid-19---an-ongoingconversation. 
bank dalam menawarkan perkhidmatan yang selari dengan permintaan pelanggan. ${ }^{19}$

Teknologi moden memberi isyarat bahawa ia bakal mengubah operasi tradisional institusi kewangan. Justeru, pengkaji dan pihak industri perbankan Islam perlu mengambil tindakan proaktif dalam meneliti konsep teknologi moden, umpamanya kontrak pintar bagi memastikan institusi perbankan Islam kekal relevan di masa hadapan di samping mengekalkan kelestariannya dalam industri kewangan Islam terpelihara. Sehubungan itu, kajian ini akan meneliti konsep kontrak pintar dan mengenal pasti kelebihannya terhadap operasi institusi perbankan Islam, khususnya dalam penawaran produk pembiayaan berasaskan tawarruq.

\section{KONSEP KONTRAK PINTAR}

\section{Definisi kontrak pintar}

Dalam penggunaan istilah teknologi, terdapat beberapa versi definisi yang dicapai melalui kajian-kajian lepas. Antaranya definisi pencetus konsep kontrak pintar, iaitu Nick Szabo, beliau mendefinisikan kontrak pintar sebagai sesuatu perjanjian dan protokol perjanjian yang dibentuk secara digital dengan menggunakan kaedah program komputer. Perkataan 'pintar' digunakan Szabo sebagai isyarat bahawa operasi kontrak pintar lebih berkesan berbanding dengan kontrak berasaskan dokumen fizikal dengan memanfaatkan teknologi digital. ${ }^{20}$ Siti Rohaya et al. (2018) berpandangan kontrak pintar merujuk kepada kodkod komputer yang berjalan di atas blok rantai. Ia mengandungi satu set peraturan yang mengikat pihak-pihak yang terlibat atau bertransaksi menerusi kontrak pintar. $^{21}$

19 Lum Kar Hoe, "Covid-19: Opportunities and Challenges For Digital Bank," laman sesawang PWC, dicapai pada 18 April 2020, https:// www.pwc.com/my/en/perspective/digital/200408-pwc-blog-covid19-opportunities-challenges-digital-banks.html.

20 Nick Szabo, "Formalizing and Securing relationships on Public Networks," Uic Journals 2, no. 9 (1997).

21 Siti Rohaya et al., "Artificial Intelligence, Smart contract and Islamic Finance," Asian Social Journal 14, no. 2 (2018), 145-154. 
Sedangkan Farukh Habib (2019) menyatakan kontrak pintar menggunakan kaedah matematik yang disebut sebagai algorisma, menyebabkan kontrak dapat berkuat kuasa secara automatik apabila terma dan syarat yang telah ditetapkan dipenuhi. ${ }^{22} \mathrm{Nicola}$ et al., (2017) dan Mark (2017) pula mendefinisikan kontrak pintar sebagai kontrak yang terlaksana sepenuhnya secara automatik apabila memenuhi terma yang telah ditetapkan dalam bentuk kod komputer dan dikuatkuasakan oleh mekanisme konsensus blok rantai. ${ }^{23}$

Asasnya, kontrak pintar wajar disinonimkan dengan kontrak tradisional, iaitu satu mekanisme yang membolehkan sesuatu transaksi dijalankan dengan ikatan undang-undang tertentu. ${ }^{24}$ Perkembangan teknologi yang kian pesat mempelbagaikan cara melaksanakan transaksi daripada tradisional yang melibatkan dokumen fizikal dan campur tangan manusia, kepada transaksi digital yang bebas dari proses dokumentasi dan kurang campur tangan manusia.

Misalnya, perubahan dalam transaksi jual beli air. Sesetengah penjual menjualnya secara fizikal dengan memerlukan pertembungan di antara dua pihak serta berlaku proses perekodan transaksi ke dalam dokumen atau buku catatan. Manakala mesin layan diri (vending machine) yang menggunakan kod komputer seperti kontrak pintar mengurangkan proses dokumentasi fizikal dan hanya melibatkan mesin untuk bertransaksi tanpa pertembungan dua pihak seperti transaksi fizikal. ${ }^{25}$

22 Farrukh Habib, "Smart Contracts for Islamic Financial Transaction," dalam IFIKR DIGEST 11 (IFIKR, Kuala Lumpur, 2019), 10-15.

23 Nicola, Massimo dan Tiziana, "A Survey of Attacks on Ethereum Smart Contracts," dalam International Conference on Principles of Security and Trust, (Springer: Berlin, Heidelberg, 2017), 164186; Mark Giancaspro, “Is A 'Smart Contract Really A Smart Idea? Insight From A Legal Perspective," Computer Law And Security Review (2017), 1-11.

24 Nick Szabo, "Formalizing and Securing relationships on Public Networks," Uic Journals 2, no. 9 (1997).

25 Mark Giancaspro, " Is A 'Smart Contract Really A Smart Idea? Insight From A Legal Perspective," Computer Law And Security Review (2017), 1-11. 
Rumusannya, konsep kontrak pintar adalah satu kontrak digital dan boleh dibahagikan kepada beberapa komponen asas. Pertama, ia adalah satu bentuk kontrak, iaitu mekanisme untuk melaksanakan transaksi bersandarkan undang-undang tertentu. Kedua, pembetukan kontrak pintar dihasilkan melalui kaedah bahasa dan penulisan kod komputer yang menyebabkan transaksi berlaku secara automatik apabila sesuatu input transaksi diterima. Ketiga, kontrak pintar beroperasi melalui rangkaian digital. Platform blok rantai merupakan satu rangkaian teknologi yang sesuai untuk melaksanakan kontrak pintar sehingga kini.

\section{Rangkaian Blok rantai}

Kontrak pintar selari dengan konsep kontrak berteraskan undangundang. Perbezaan kontrak pintar dan kontrak tradisional terletak pada kaedah operasinya. Kontrak tradisional dilaksanakan melalui kaedah dokumentasi serta pelaksanaan fizikal secara penuh atau separa digital. ${ }^{26}$ Manakala kontrak pintar hanya melibatkan teknologi digital untuk beroperasi. Peserta kontrak pintar berinteraksi dan bertransaksi melalui peranti digital yang disebut sebagai nod. Teknologi rangkaian blok rantai menjadi platform untuk melaksanakan transaksi dan menyimpan rekod transaksi. ${ }^{27}$

Cetusan idea kontrak pintar sekitar tahun 90-an oleh Nick Szabo kurang menerima perhatian disebabkan inovasi teknologi yang terhad dan tiada rangkaian atau platform yang dapat menyokong operasi kontrak pintar. ${ }^{28}$ Namun begitu, perkembangan teknologi rangkaian blok rantai kepada blok rantai 2.0 kini bukan sahaja dapat melaksanakan transaksi mata wang kripto, malah dapat melaksanakan terma kontrak pintar secara desentralisasi dan

26 Mark Giancaspro, “ Is A 'Smart Contract Really A Smart Idea? Insight From A Legal Perspective," Computer Law And Security Review (2017), 1-11.

27 Az Azrinudin, Abdo Ali Abdullah dan Zamri Yusoff, "Overview of Blockchain Implementation on Islamic Finance: Saadiqin Experience," (makalah: 2018 Cyber Resilience Conference (CRC), t.t., 2018), 1-2.

28 Mark Giancaspro, "Is A 'Smart Contract Really A Smart Idea? Insight From A Legal Perspective," Computer Law and Security Review (2017), 1-11. 
teredar (distributed). Sesetengah pengkaji mendakwa kontrak pintar merupakan salah satu ciri-ciri terbaru blok rantai. Disebabkan itu, konsep kontrak pintar mendapat perhatian dalam kalangan pengkaji dan pemain teknologi. ${ }^{29}$

Dalam penggunaan istilah pemain teknologi dan akademik, perkataan blok rantai dan kontrak pintar digunakan secara bersilih ganti. Ia disebabkan oleh kontrak pintar dijalankan melalui rangkaian blok rantai. Hakikatnya, kontrak pintar merupakan satu skrip kod komputer atau program komputer yang mewakili terma sesuatu transaksi dan ia dilaksanakan secara automatik apabila terma yang ditetapkan dipenuhi. Ia berperanan sebagai alternatif kepada operasi kontrak tradisional dengan kurang melibatkan campur tangan manusia dalam operasi.

Manakala blok rantai merujuk kepada satu rangkaian teknologi berperanan untuk melaksanakan transaksi secara desentralisasi dan menyimpan rekod transaksi secara teredar (distributed), antaranya rekod jenis, jumlah dan masa transaksi. ${ }^{30}$ Selain itu, blok rantai turut mampu menjadi rangkain kepada mata wang kripto, perkhidmatan storan awan (cloud storage), pemindahan wang (remmittance), zakat dan wakaf. ${ }^{31}$ Secara asasnya, rajah 1 mengilustrasikan mekanisme blok rantai:

\section{Ibid.}

30 Christian Catalini dan Joshua, "Some Simple Economics of the Blockchain," laman sesawang SSRN, dicapai pada 12 Julai 2020, https://papers.ssrn.com/sol3/papers.cfm?abstract_id=2874598.

31 Hussein Elasrag, "Blockchains for Islamic Finance: Obstacles \& Challenges," MPRA (2019), 1-32. 
Rajah 1: Ilustrasi transaksi mata wang kripto menggunakan platform blok rantai

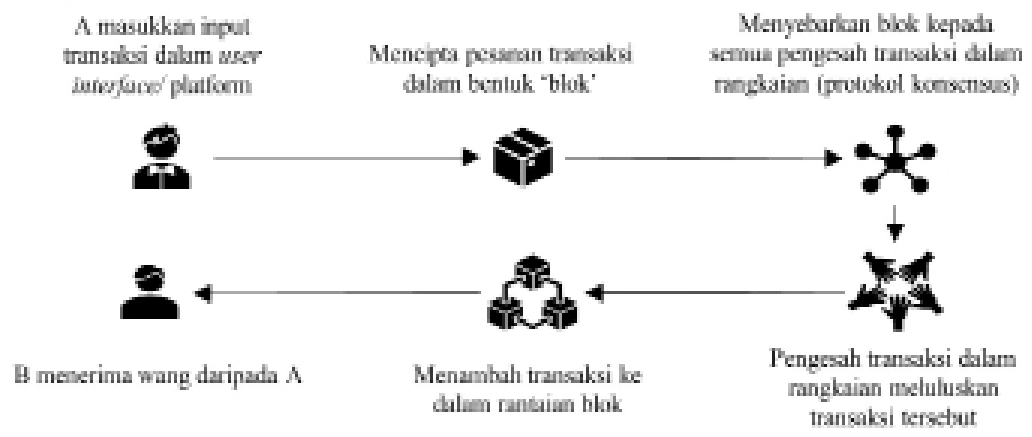

Sumber: Olahan dari rajah Peter Eza, Tochukwu dan Chinedu, 2017.32

Berdasarkan rajah 1, apabila A menghantar wang kepada $\mathrm{B}$ dalam rangkaian blok rantai, beliau perlu memasukkan input spesifik ke dalam antara muka pengguna (user interface) platform tersebut yang berupa pesanan melakukan transaksi. Pesanan tersebut akan ditukarkan ke dalam bentuk blok dan disebarkan kepada pihak pengesah transaksi dalam rangkaian untuk disahkan. Kaedah pengesahan transaksi dalam blok rantai bervariasi, bergantung kepada jenis protokol konsensus yang digunakan, umpamanya proof-of-work, proof-of-stake dan byzantine fault tolerance. ${ }^{33}$

Kesemua jenis protokol konsensus mempunyai protokol pengesahan transaksi yang berbeza dan penggunaan mata wang kripto yang berlainan sebagai ganjaran kepada pengesah transaksi di atas kerja pengesahan transaksi yang telah dilakukan dalam rangkaian. Umpamanya, platform blok rantai Ethereum, menggunakan protokol konsensus proof-of-stake atau proofof-work dan mata wang kripto Ether sebagai ganjaran kepada pengesah transaksi. Manakala platform blok rantai Bitcoin mengaplikasi protokol konsensus proof-of-work dan mata wang

32 Peter Eza, Tochukwu dan Chinedu, "A Triplicate Smart Contract Model using Blockchain Technology," Circulation in Computer Science-Special Issue (2017), 1-10.

Ibid. 
kripto Bitcoin sebagai ganjaran pengesahan transaksi. Namun kesemua protokol konsensus mempunyai matlamat yang sama, iaitu mengesahkan transaksi dan menyimpan rekod transaksi ke dalam rangkaian blok rantai. Apabila transaksi disahkan, rekod transaksi akan disimpan dalam bentuk blok yang dihubungkan dengan blok-blok sebelumnya dalam rangkaian blok rantai tanpa mengubah data-data blok sebelumnya. Setelah selesai, B akan menerima wang daripada A. ${ }^{34}$

Blok-blok dalam rangkaian blok rantai berbentuk kriptografi yang kompleks. Setiap blok mempunyai perincian transaksi, umpamanya masa dan jumlah transaksi serta pihak bertransaksi. ${ }^{35}$ Blok tersebut akan ditukar kepada set nombor khusus yang dikenali sebagai hash. Pembentukan sesuatu hash tidak menerima sebarang perubahan atau pembetulan. Bahkan sekiranya terdapat pihak yang cuba mengubahnya, hash baharu akan terbentuk dan disambung kepada rantaian blok yang sedia ada. Kesannya, rekod transaksi yang telah dilakukan tidak boleh diubah dan bersifat kekal. Ciri-ciri tersebut menyebabkan transaksi yang dilaksanakan melalui rangkaian blok rantai mempunyai sekuriti yang baik. ${ }^{36}$

Dalam penggunaan istilah teknologi, rangkaian blok rantai dikenali dengan beberapa terma, antaranya aplikasi desentralisasi (DApps) dan kewangan desentralisasi (DeFi). Rangkaian ini memiliki tiga elemen penting iaitu (i) transaksi, (ii) rekod transaksi dan (iii) mekanisme untuk pengesahan dan

34 Nur Husna Zakaria, Sherin Kunhibava, Md. Ershadul Karim, Abu Bakar Munir dan Raphael Kok, Thing Ming Sen dan Ridoan Karim, "Malaysian Blockchain Regulatory Report," https://law.um.edu. my/Research-UMCORS/RegTech/UM\%20-\%20Malaysian\%20 Blockchain\%20Regulatory\%20Research\%20Report.pdf.

35 Christian Catalini dan Joshua, "Some Simple Economics of the Blockchain," laman sesawang SSRN, dicapai pada 12 Julai 2020, https://papers.ssrn.com/sol3/papers.cfm?abstract_id=2874598.

36 Cointeghraph, "How blockchain technology works. Guide for beginners," laman sesawang Cointelegraph, dicapai pada 12 April 2021, https://cointelegraph.com/bitcoin-for-beginners/howblockchain-technology-works-guide-for-beginners\#: :text=A\%20 Blockchain \%20is\%20a\%20type,Each\%20transaction \%20 generates $\% 20 \mathrm{a} \% 20$ hash.\&text $=$ Each $\% 20$ block $\% 20$ refers $\% 20$ to $\% 20$ the, $\mathrm{a} \% 20$ copy $\% 20$ of $\% 20$ the $\% 20$ Blockchain. 
penyimpanan transaksi. ${ }^{37} \mathrm{Di}$ samping itu, blok rantai mempunyai beberapa kriteria khusus dalam operasinya. Pertama, blok rantai melaksanakan transaksi secara desentralisasi. Segala transaksi yang berlaku tidak disahkan oleh pihak berautoriti, sebaliknya melalui mekanisme protokol konsensus, bergantung kepada jenis konsensus yang digunakan dalam rangkain blok rantai. ${ }^{38}$ Kedua, rekod secara teredar (distributed). Semua rekod transaksi disimpan di dalam rangkaian blok rantai disebarkan kepada semua peserta rangkaian secara masa sebenar. Ketiga, transaksi yang telah disahkan dan membentuk blok dalam rantaian blok rantai tidak boleh dipadam dan dimodifikasi (immutable). Dengan itu, setiap pihak bertransaksi dapat melihat rekod transaksi yang sebenar tanpa halangan pada bila-bila masa. ${ }^{39}$ Kriteria yang terdapat dalam teknologi blok rantai menyebabkan ia sesuai diintegrasi bersama konsep kontrak pintar.

Rumusannya, blok rantai merupakan satu rangkaian yang mampu melaksanakan konsep kontrak pintar. Meskipun rangkaian ini sering dikaitkan dengan transaksi mata wang kripto seperti Bitcoin dan Ether, ia mempunyai kemampuan untuk melaksanakan transaksi lain, antaranya kontrak pintar.

\section{Ciri-ciri Kontrak pintar}

Kontrak pintar yang berasaskan blok rantai mempunyai beberapa ciri unik. Pertama, kontrak pintar bersifat digital. Ia tidak memerlukan dokumen dan proses fizikal dalam operasinya. Sebaliknya, pembentukan kontrak pintar berasaskan kepada kod komputer. Kod-kod tersebut mewakili terma kontrak dan transaksi. Apabila sesutatu perjanjian telah disepakati oleh pihak-

37 Aishath Muneeza \& Zakariya Mustapha, "Blockchain and Its Shariah Compliant Structure," dalam Halal Cryptocurrency Management (Cham: Palgrave Macmillan, 2019), 69-106.

38 Peter Eza, Tochukwu dan Chinedu, "A Triplicate Smart Contract Model using Blockchain Technology," Circulation in Computer Science-Special Issue, (2017), 1-10 ; Eliza MIK, "Smart Contracts: Terminology, Technical Limitations and Real World Complexity," Law, Innovation and Technology 9, no. 2 (2017), 269-300.

39 Nor Razinah, "Smart Contract in Blockchain: An Exploration of Legal Framework in Malaysia," Intellectual Discourse 27, no. 2 (2019), 595-617. 
pihak yang bertransaksi, terma-terma tersebut akan dikodkan oleh pemprogram komputer dalam bahasa program komputer yang khusus bagi membentuk kontrak pintar. Hal ini menjadikan kontrak yang dibentuk bukan lagi secara dokumen fizikal, tetapi bersifat digital. ${ }^{40}$

Kedua, pelaksanaan kontrak secara kendiri atau automatik. Selepas kontrak pintar dibentuk dan disebarkan (deployed) ke dalam rangkaian blok rantai, kontrak akan terlaksana secara automatik apabila terma dipatuhi oleh pihak-pihak yang berkontrak. ${ }^{41}$ Ciriciri ini menyebabkan operasi transaksi yang dijalankan melalui kontrak pintar selari dan konsisten dengan terma yang dikodkan tanpa berlaku pelanggaran dengan mana-mana terma yang telah ditetapkan. ${ }^{42}$ Misalnya, 1000 orang melaksanakan satu transaksi pelaburan menggunakan kontrak pintar. Mereka bersetuju bahawa setiap daripada mereka akan memperolehi dividen secara sama rata selepas 15 tahun tempoh kontrak. Maka, kontrak pintar akan memastikan dividen tersebut akan diagihkan secara sama rata selepas 15 tahun selari dengan terma yang termaktub dalam kontrak pintar.

Ketiga, transaksi disahkan secara desentralisasi, iaitu pengesahan transaksi dilakukan oleh komuniti dalam rangkaian blok rantai tanpa melibatkan pihak berautoriti. Transaksi yang dilakukan melalui rangkain blok rantai akan melalui proses pengesahan transaksi yang dinamakan sebagai protokol konsensus. Kaedahnya bervariasi bergantung kepada jenis blok rantai yang digunakan dan jenis protokol konsensus yang diaplikasi. Namun, kesemua kaedah tersebut mempunyai matlamat yang sama, iaitu

40 Farhana dan Faridah, "Smart contract in Islamic Trade Finance," dalam Contemporary Management and Science Issues, (Singapore: Springer Publisher, 2019), 431-437.

41 Tianyu Feng, Xiao Yu, Yueting Chai dan Yi Liu, "Smart Contract Model For Complex Reality Transaction," International Journal of Crowd Science 3, no. 2 (2019), 194-197.

42 Farhana dan Faridah, "Smart contract in Islamic Trade Finance," dalam Contemporary Management and Science Issues, (Singapore: Springer Publisher, 2019), 431-437. 
memastikan transaksi dalam blok rantai disahkan dan direkod dalam rangkaian blok rantai. ${ }^{43}$

Keempat, tidak boleh diubah atau dimodifikasi (immutable). Setelah kontrak pintar dikodkan dan disebarkan (deployed) ke dalam blok rantai, ia tidak menerima sebarang pemindaan. Segala terma yang dikodkan dalam kontrak pintar dilaksanakan secara aturan yang telah termaktub apabila menerima input spesifik daripada pengguna atau pihak yang bertransaksi dalam platform blok rantai. Tambahan lagi, rekod transaksi yang telah disahkan dan disimpan dalam rangkaian blok rantai tidak boleh dimodifikasi atau dibatalkan. ${ }^{44}$

Kelima, rekod transaksi secara teredar (distributed). Setelah transaksi disahkan melalui proses protokol konsensus yang khusus, satu blok akan terbentuk. Blok yang mewakili transaksi tersebut kemudiannya akan dihubungkan dengan blok-blok lain dalam rangkaian blok rantai yang mewakili transaksi yang telah berlaku dan disahkan sebelumnya. ${ }^{45}$ Blok-blok tersebut bersifat teredar. Ini bermakna, ia akan disebarkan kepada setiap nod yang menyertai rangkaian blok rantai tersebut dan menyebabkan semua nod tersebut dapat melihat rekod transaksi secara masa sebenar. ${ }^{46}$

43 Shahbaz Alam dan Hina Noor, "Mined and Non-Mined Crypto Currencies: A Critical Analysis from Shariah Perspective," International Journal of Innovative Science and Research Technology 5, no. 3 (2020), 429-437.

44 Romulo Luciano, "The Hazards of Misusing the Smart Contract: An AHP Approach to Its Risk," JIS 10(1), (2019), https://www. scirp.org/html/2-7800557_90112.htm; Aishath Mueza \& Zakariya Mustapha, "Blockchain and Its Shariah Compliant Structure," dalam Halal Cryptocurrency Management (Cham: Palgrave Macmillan, 2019), 69-106.

45 Peter Eza, Tochukwu dan Chinedu, "A Triplicate Smart Contract Model using Blockchain Technology," Circulation in Computer Science-Special Issue, (2017), 1-10 ; Eliza MIK, "Smart Contracts: Terminology, Technical Limitations and Real World Complexity," Law, Innovation and Technology 9, no. 2 (2017) 269-300.

46 Nor Razinah, "Smart Contract in Blockchain: An Exploration of Legal Framework in Malaysia," Intellectual Discourse 27, no. 2 (2019), 595-617; Ilinka Antova dan Tahar Tayachi, "Blockchain and smart contracts: A Risk Manegement Tool for Islamic Finance," Journal of Islamic Financial Studies 5, no. 1 (2019), 29-42. 


\section{Struktur Asas Kontrak Pintar}

Asasnya, operasi kontrak pintar berasaskan teknologi blok rantai dapat dilihat melalui rajah 2:

Rajah 2: Struktur dan proses kontrak pintar berasaskan blok rantai

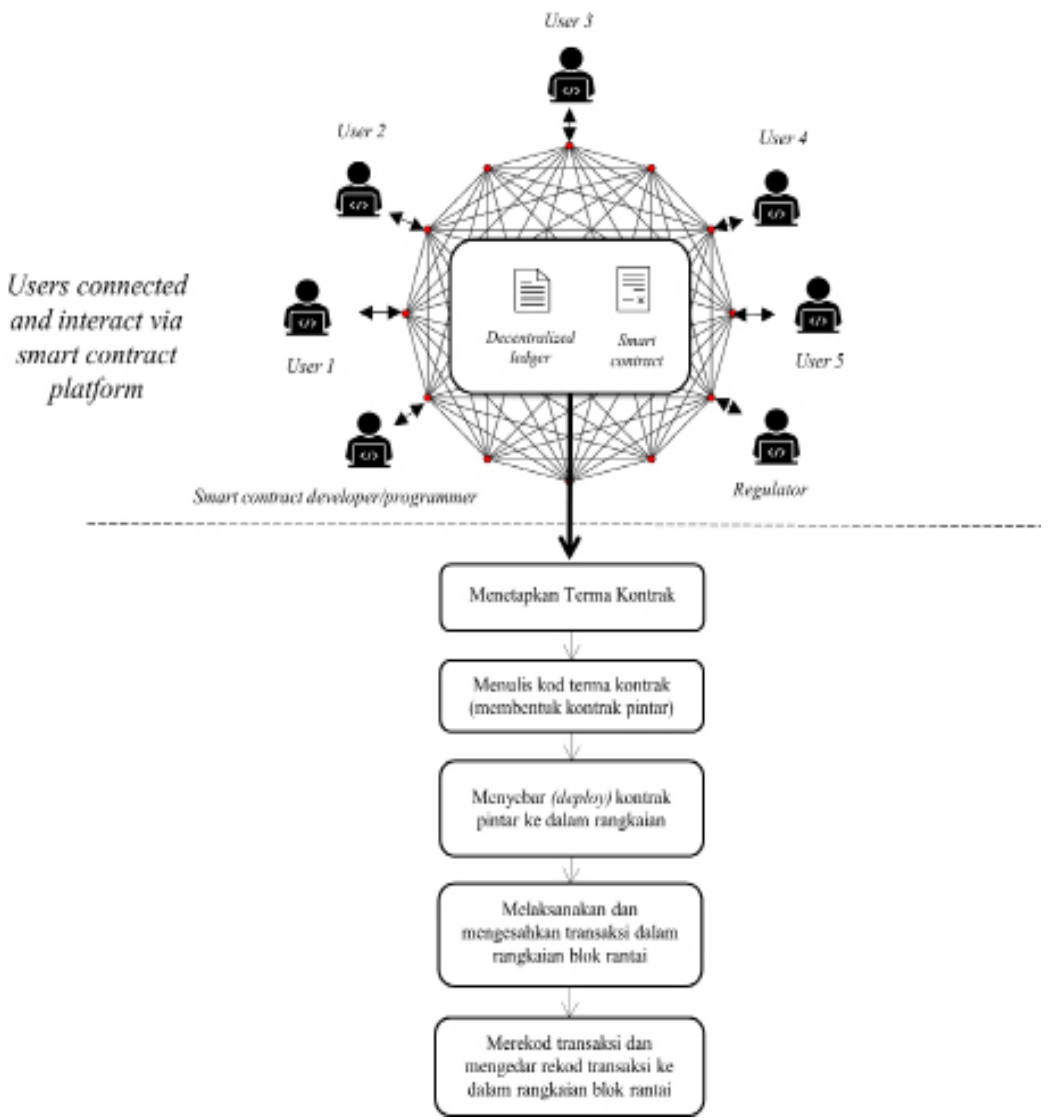

Sumber: Olahan daripada Tianyu et al., (2019) dan Business and Beyond (2016). ${ }^{47}$

47 Tianyu Feng, Xiao Yu, Yueting Chai dan Yi Liu, "Smart Contract Model For Complex Reality Transaction," International Journal of Crowd Science 3, no. 2 (2019), 194-197 ; Alliance, Smart Contracts. "Smart Contracts: 12 Use Cases for Business \& Beyond" (Laporan: Chamber of Digital Commerce, Washingon D.C, 2016), 1-53. 
Berdasarkan rajah 2 di atas, setiap pihak yang terlibat dengan transaksi akan dihubungkan dan bertransaksi dalam platform kontrak pintar. Pemaju/pemprogram kontrak pintar (smart contract developer/programmer) berperanan membentuk kontrak pintar dengan mengekod terma kontrak yang dipersetujui oleh peserta kontrak. Peserta kontrak dalam platform blok rantai dapat melihat setiap transaksi yang telah berlaku dalam rangkaian tersebut. Dalam pada itu, pihak pengawal selia (regulator) juga boleh berada dalam rangkaian blok rantai sekiranya memerlukan penilaian dari pihak pengawal selia transaksi.

Seterusnya, pembentukan kontrak pintar dan pelaksanaan transaksi dalam rangkaian blok rantai akan melalui empat proses asas. Pertama, menetapkan terma kontrak di antara pihak-pihak yang bertransaksi, umpamanya peserta kontrak, subjek kontrak, harga kontrak, tempoh kontrak dan tindakan ke atas pelanggaran terma kontrak. Kedua, membentuk kontrak pintar dengan menulis terma kontrak dalam bentuk kod berdasarkan bahasa program komputer yang khusus. Ketiga, menyebarkan (deploy) kod kontrak pintar ke dalam rangkaian blok rantai. Keempat, melaksanakan dan mengesahkan transaksi dalam rangkaian blok rantai. Bagi melaksanakan transaksi, pengguna atau pihak yang bertransaksi memasukkan input spesifik transaksi ke dalam antara muka (user interface) atau platform blok rantai. Pengesah transaksi yang menyertai rangkaian tersebut akan mengesahkan input transaksi tersebut secara protokol konsensus yang ditetapkan dalam rangkaian tersebut. ${ }^{48}$ Keempat, merekod transaksi ke dalam rangkaian blok rantai dan mengedar rekod transaksi kepada semua nod atau peserta dalam rangkaian blok rantai.

\section{POTENSI MENGINTEGRASI TEKNOLOGI KONTRAK PINTAR KE DALAM OPERASI PEMBIAYAAN BERASASKAN KONTRAK TAWARRUQ}

Kontrak tawarruq dalam perbankan Islam merupakan kontrak yang melibatkan dua kontrak jual beli. Pertama melibatkan penjualan aset oleh penjual kepada pembeli secara bayaran tertunda. Kedua,

${ }_{48}$ Peter Eza, Tochukwu dan Chinedu, "A Triplicate Smart Contract Model using Blockchain Technology," Circulation in Computer Science-Special Issue, (2017), 1-10. 
pembeli pertama akan menjual aset yang sama kepada pihak ketiga secara bayaran tunai dan spot. ${ }^{49}$ Rajah 3 merupakan operasi kontrak tawarruq di perbankan Islam:

Rajah 3: Model Pembiayaan Berasaskan Tawarruq

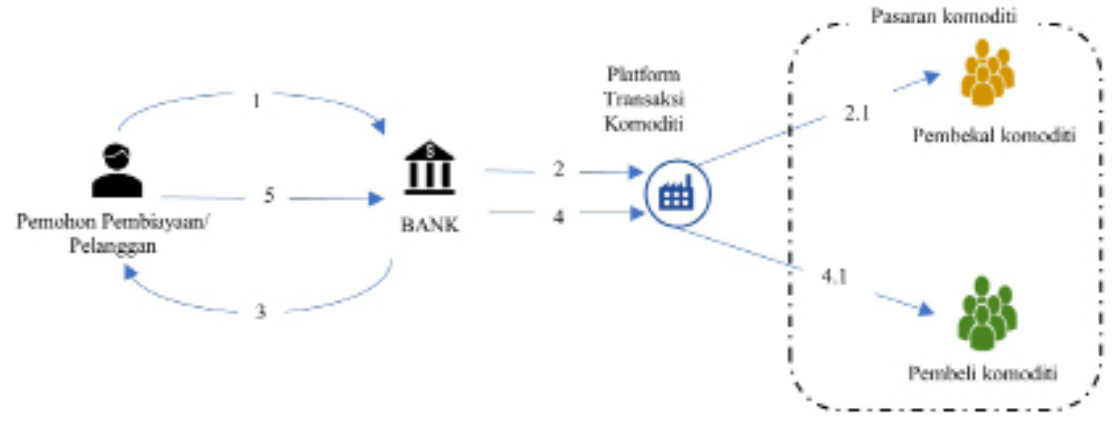

Sumber: Olahan model Ellida Fauziah et al., 2017

a) Pelanggan membuat permohonan pembiayaan berasaskan tawarruq dan melengkapkan borang produk yang berkaitan.

b) Bank membeli komoditi dari pembekal komoditi di platform komoditi yang dilanggan oleh bank.

c) Bank menjual komoditi tersebut kepada pelanggan secara murābhah, iaitu harga kos ditambah keuntungan. Proses pembelian akan dilakukan oleh bank sebagai wakil bagi pihak pelanggan.

d) Pelanggan sekali lagi mewakilkan pihak bank menjual komoditi tersebut kepada pembeli komoditi di platform komoditi secara bayaran tunai dengan harga kos komoditi.

e) Pihak pelanggan membayar hutang kepada pihak bank secara ansuran mengikut terma kontrak pembiayaan yang dipersetujui

49 Bank Negara Malaysia, "Dokumen Polisi Tawarruq," laman sesawang Bank Negara Malaysia, dicapai pada 11 Februari 2021, $\quad$ https://www.bnm.gov.my/documents/20124/938039/ pd_reissuancetawarruq_dec2018.pdf/bcc4b359-381c-5035-f9f03908 faebb92a?t=1592249563244

50 Ellida Fauziah et al., "Tawarruq as a Product for Financing within the Islamic Banking System: A Case Study of Malaysian Islamic Banking System," International Journal of Management and Applied Research 4, no. 1 (2017), 32-43. 
bersama.

Ilustrasi dalam rajah 3 merupakan satu proses asas produk pembiayaan tawarruq di perbankan Islam Malaysia. Secara konteksnya, pelanggan perlu memohon produk pembiayaan di perbankan Islam. Dalam beberapa tempoh setelah pihak bank melakukan penilaian kredit untuk pelanggan dan meluluskan permohonan tersebut, pelanggan akan menerima surat tawaran (Letter of offer) produk pembiayaan yang mempunyai terma dan syarat pembiayaan yang dimohon. Pelanggan perlu menandatangani borang tersebut menandatakan persetujuan terhadap terma dan syarat pembiayaan yang ditawarkan. Selepas selesai, pihak bank akan melaksanakan transaksi tawarruq. Terdapat staf yang dikhususkan untuk memasukkan perincian jumlah belian ke dalam sistem Perkhidmatan Islam Bursa Malaysia (BMIS) pada setiap hari untuk membeli komoditi dari pembekal komoditi. Setelah itu, komoditi tersebut akan dijual kepada pelanggan dengan berwakilkan pihak bank secara jual beli dalam sistem. Setelah itu, staf tersebut akan mewakili pelanggan sekali lagi dalam proses jualan semula komoditi melalui sistem BMIS. Setiap rekod transaksi jual beli komoditi akan disimpan di bank dengan bukti E-sijil (E-certificate) jual beli komoditi di sistem BMIS. ${ }^{51}$ Kemudian, sistem BMIS akan membayar kepada pelanggan dengan mengarahkan pihak bank untuk mendebitkan ke akaun pelanggan. Akhirnya, pelanggan akan membayar semula hutang dengan pihak bank mengikut tempoh yang termaktub dalam kontrak yang dipersetujui.

Pelaksanaan pembiayaan berasaskan tawarruq berpotensi dilaksanakan dengan menggunakan teknologi kontrak pintar. ${ }^{52}$ Hal ini dapat dilihat melalui beberapa kajian, antaranya kajian

${ }_{51}$ Mohd Izuwan, "Aplikasi Tawarruq dalam Sistem Perbankan Islam: Kajian di Bank Muamalat Malaysia Berhad" (Tesis sarjana, Universiti Malaya, Kuala Lumpur, 2015), 76.

52 Aishath Muneeza \& Zakariya Mustapha, "Blockchain and Its Shariah Compliant Structure," dalam Halal Cryptocurrency Management (Cham: Palgrave Macmillan, 2019). 
Akram Laldin, ${ }^{53}$ Aishath Muneeza et al., ${ }^{54}$ Faruq Roslan et al. ${ }^{55}$ dan Farukh Habib. ${ }^{56}$ Mereka mencadangkan secara langsung dan tidak langsung bahawa transaksi-transaksi kewangan Islam, antaranya transaksi tawarruq dilaksanakan melalui teknologi kontrak pintar dan blok rantai. Khususnya kajian Faruq et al. (2020) mengilustrasikan perubahan operasi transaksi tawarruq menggunakan teknologi kontrak pintar dan blok rantai. Proses transkasi tawarruq dikodkan dalam kontrak pintar dan disebarkan dalam platform blok rantai. Apabila platform blok rantai menerima input transaksi yang selari dengan kod kontrak pintar, transaksi akan terlaksana secara automatik dengan melalui pengesahan transaksi (protokol konsensus) yang khusus dan transaksi akan direkodkan secara tredar (distributed). Ini menyebabkan pengurangan campur tangan manusia dan penglibatan dokumen fizikal dalam operasi.

Namun, kajian-kajian berkenaan kontrak Syariah seperti murābaḩah dan tawarruq menggunakan teknologi kontrak pintar dan blok rantai seperti kajian Faruq Roslan et al. ${ }^{57}$ dan Farukh Habib $^{58}$ merupakan kajian potensi yang belum diaplikasi secara spesifik di Malaysia. Para pengkaji bersandarkan kepada kajiankajian lepas yang membincangkan tentang teknologi ini yang telah diaplikasi dalam produk dan servis lain yang menggunakan kontrak pintar dan blok rantai. Mereka kemudiannya mengilustrasikan

53 Akram Laldin, "Fintech and Shariah Governance" laman sesawang Islamic Finance News, dicapai pada 20 Disember 2019, https:// islmfintech.com/wp-content/uploads/2017/06/Fintech-and-Shariahgovernance-_-Islamic-Finance-News.pdf.

54 Aishath Muneeza \& Zakariya Mustapha, "Blockchain and Its Shariah Compliant Structure," dalam Halal Cryptocurrency Management (Cham: Palgrave Macmillan, 2019).

55 Muhammad Faruq et al., "Application of Tawarruq in Islamic Banking in Malaysia: Towards Smart Tawarruq," IJMAR 7(2), (2019), 100-113.

56 Farrukh Habib, "Smart Contracts for Islamic Financial Transaction," dalam IFIKR DIGEST 11, (IFIKR, Kuala Lumpur, 2019), 10-15.

57 Muhammad Faruq et al., "Application of Tawarruq in Islamic Banking in Malaysia: Towards Smart Tawarruq," IJMAR 7, no. 2 (2019), 100-113.

58 Farrukh Habib, "Smart Contracts for Islamic Financial Transaction," dalam IFIKR DIGEST 11, (IFIKR, Kuala Lumpur, 2019), 10-15. 
operasi tawarruq melalui ekosistem teknologi kontrak pintar dan rangkaian blok rantai yang sedia ada. Rajah 4 merupakan ilustrasi asas produk pembiayaan berasaskan tawarruq menggunakan kontrak pintar:

Rajah 4: Ilustrasi Asas Produk Pembiayaan Berasaskan Tawarruq menggunakan Kontrak Pintar

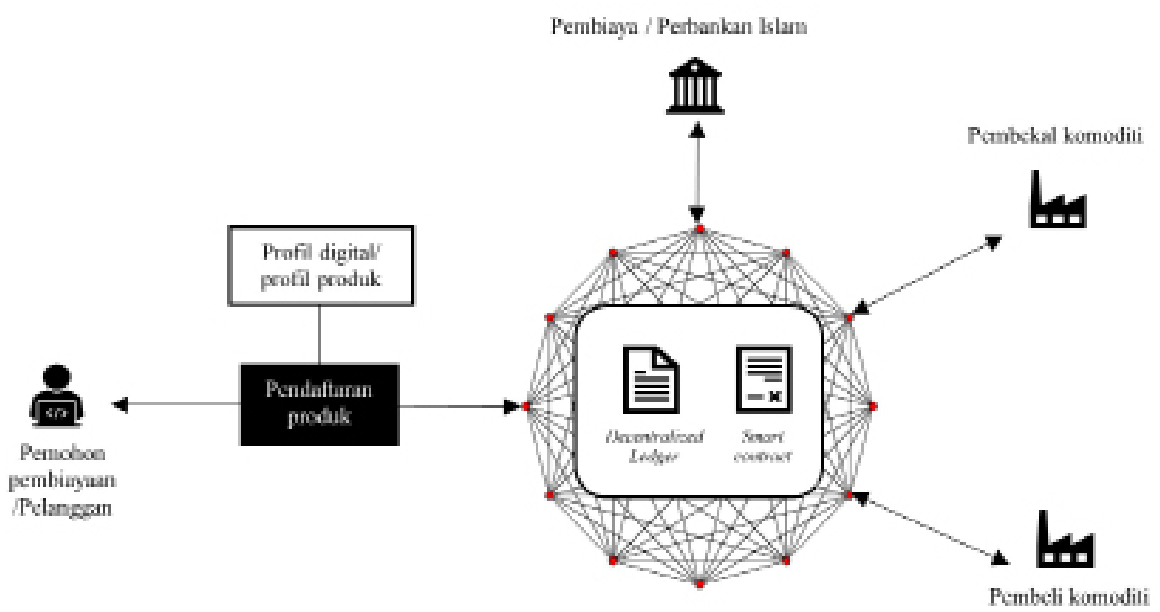

Sumber: Olahan dari rajah Faruq Roslan et al., 2020. ${ }^{59}$

Berdasarkan rajah 4, proses dimulakan dengan permohonan pembiayaan oleh pelanggan. Proses ini boleh berlaku melalui integrasi teknologi lain untuk mengautomasikan operasi seperti teknologi kecerdasan buatan (artificial intelligence) dan teknologi data raya (big data) bagi proses memadankan pelanggan dengan pembiayaan yang sesuai. Teknologi ini dapat melakukan proses pemadanan dan penilaian secara dua hala. Pihak pembiaya dapat melakukan penyaringan penilaian kredit dengan lebih pantas dan efisien. Pelanggan pula dapat memilih pembiayaan yang terbaik dari sudut-sudut tertentu, umpamanya perkhidmatan terbaik, peratus keuntungan yang lebih rendah atau kepatuhan Syariah. ${ }^{60}$

59 Muhammad Faruq et al., "Application of Tawarruq in Islamic Banking in Malaysia: Towards Smart Tawarruq," IJMAR 7, no. 2 (2019), 100-113.

Ibid. 
Setelah proses pendaftaran produk, penyesuaian produk dan terma kontrak di antara pelanggan dan pembiaya dibentuk, proses penulisan kod terma akan dilakukan. Pemprogram komputer (computer programmer) akan membentuk kontrak pintar yang selari dengan terma tersebut dan menyebarkan (deploy) kontrak pintar ke dalam rangkaian blok rantai. Kontrak pintar akan mengikat kesemua pihak yang terlibat, iaitu pihak pelanggan, bank Islam/pembiaya, pembekal komoditi dan pembeli komoditi.

Proses transaksi tawarruq akan terlaksana secara automatik apabila menerima input spesifik jual beli yang selari dengan terma yang telah ditetapkan dalam platform blok rantai. Pengesahan transaksi berlaku secara desentralisasi melalui kaedah protokol konsensus dan transaksi direkod secara teredar (disributed). Proses kontrak pintar akan berjalan sehingga terma yang termaktub dalam bentuk kod komputer selesai dilaksanakan. ${ }^{61}$

Berdasarkan potensi peralihan kepada penggunaan kontrak pintar dan operasi pembiayaan berasaskan tawarruq, kajian merumuskan beberapa perbezaan operasi:

Jadual 1: Perbezaan operasi transaksi tawarruq di perbankan Islam dan operasi menggunakan kontrak pintar

\begin{tabular}{ccc}
\hline Kunci Perbezaan & Operasi Semasa & $\begin{array}{c}\text { Operasi Kontrak } \\
\text { Pintar }\end{array}$ \\
\hline $\begin{array}{c}\text { Pelaksanaan } \\
\text { transaksi }\end{array}$ & $\begin{array}{c}\text { Dilaksanakan oleh } \\
\text { manusia }\end{array}$ & $\begin{array}{c}\text { Dikuatkuasakan } \\
\text { oleh kod kontrak } \\
\text { pintar }\end{array}$ \\
Pengesahan transaksi & Disahkan oleh & Disahkan \\
& $\begin{array}{c}\text { institusi dan pihak } \\
\text { yang bertransaksi }\end{array}$ & $\begin{array}{c}\text { secara protokol } \\
\text { konsensus }\end{array}$ \\
Rekod transaksi & Direkod secara & Direkod secara \\
& berpusat & desentralisasi
\end{tabular}

${ }^{1}$ Ibid. 


\section{KEBAIKAN MENGINTEGRASI TEKNOLOGI KONTRAK PINTAR KE DALAM OPERASI PEMBIAYAAN BERASASKAN TAWARRUQ}

Berdasarkan potensi mengitegrasi teknologi kontrak pintar ke dalam operasi kontrak tawarruq di perbankan Islam, kajian merumuskan dua impak dan kebaikan yang berpotensi diperoleh. Pertama, kadar ketelusan operasi berupaya ditingkatkan. Jika diteliti operasi tawarruq di perbankan Islam, transaksi dilakukan sepenuhnya dan disahkan oleh institusi tersebut melalui buktibukti dokumen sebagai bukti transaksi. Hal ini selari dengan prinsip muamalat Islam yang menetapkan transaksi jual beli perlu disertakan dengan bukti transaksi. Namun, ketelusan operasi transaksi dapat ditingkatkan dengan menggunakan teknologi kontrak pintar dan blok rantai. Ini kerana segala transaksi dalam blok rantai akan disahkan secara desentralisasi melalui protokol konsensus yang khusus.

Kaedah protokol konsensus blok rantai meningkatkan kadar ketelusan transaksi di antara pihak yang saling tidak mengenali tanpa penglibatan pihak berautoriti. Pengesah transaksi yang menyertai protokol konsensus blok rantai menjamin transaksi yang dijalankan selari dengan terma dan menghalang dari manamana pihak melanggar terma kontrak. ${ }^{62}$ Misalnya, transaksi mata wang kripto di antara pihak A dan pihak B dalam perbincangan rangkaian blok rantai sebelum ini. Ia merupakan contoh praktikal dalam transaksi mata wang kripto yang menggunakan platform blok rantai seperti Bitcoin dan Ethereum. Mata wang kripto berjaya dihantar dari satu pihak kepada pihak lain dengan disahkan secara mekanisme protokol konsensus blok rantai yang telus. Sekiranya transaksi tawarruq dapat dilaksanakan melalui teknologi blok rantai, maka setiap transaksi jual beli akan melalui

62 Suruchi Mann, Raj Shkhar dan Anulipt Chandan, "Blockchain Technology for Supply Chain Traceability, Transparency and Data Provenance," (makalah: 2018 International Conference on Blockchain Technology and Application, Xian, China, 2018), 2226; Pieter Harte dan Mark Van Staalduinen, Truffle Test for FreeReplaying Ethereum Smart Cotnracts for Transparency, ArXiv, (2019), 1-20. 
protokol konsensus yang khusus dan mencapai tahap ketelusan yang tinggi seperti transaksi-transaksi mata wang kripto.

Selain itu, ketelusan operasi juga dapat ditingkatkan melalui rekod transaksi secara teredar (distributed) dalam rangkaian blok rantai. Merujuk kepada operasi semasa transaksi tawarruq di perbankan Islam, rekod transaksi tawarruq disimpan dalam sistem perbankan Islam. Meskipun pelanggan telah mengetahui perincian transaksi sebelum transaksi dilaksanakan berdasarkan terma kontrak, rekod transaksi tawarruq yang telah dilaksanakan hanya disimpan di institusi perbankan tersebut dalam bentuk e-sijil (e-certificate) tanpa diedarkan kepada pelanggan. ${ }^{63}$

Sekiranya kontrak pintar digunakan dalam transaksi tawarruq, ketelusan operasi dapat ditingkatkan. Operasi kontrak pintar membolehkan setiap nod yang bertransaksi berhubung melalui platform kontrak pintar dan membenarkan nod-nod tersebut melihat rekod transaksi yang telah disah dan direkod dalam rangkaian blok rantai secara masa sebenar. Ini kerana, rangkaian ini bersifat teredar (distributed), iaitu rekod transaksi disebarkan kepada nod-nod dalam rangkaian blok rantai. Setiap platform blok rantai mempunyai platform peneroka blok rantai (blockchain explorer) tersendiri untuk pengguna blok rantai mengakses data dan rekod transaksi secara masa sebenar. ${ }^{64}$ Umpamanya Etherscan, peneroka blok rantai bagi pengguna yang melaksanakan transaksi melalui platform blok rantai Ethereum. ${ }^{65}$ Ekosistem blok rantai menjadikan transaksi yang dijalankan melaluinya mempunyai

63 Mohd Izuwan Mahyudin dan Azizi Che Seman, "The Application of Bay'al-Tawarruq in Islamic Banking Institutions in Malaysia," dalam New Developments in Islamic Economics, (Bingley: Emerald Publishing Limited, 10-12 Disember 2018), 169-179.

64 Pieter Harte dan Mark Van Staalduinen, Truffle Test for FreeReplaying Ethereum Smart Cotnracts for Transparency, ArXiv, (2019), 1-20.

65 Etherscan, "About Etherscan," laman sesawang Etherscan, dicapai pada 25 Julai 2021, https://etherscan.io/. 
tahap ketelusan yang tinggi ${ }^{66}$ yang belum pernah dialami dalam praktis transaksi sebelum ini. ${ }^{67}$ Justeru itu, dengan menggunakan kontrak pintar dalam transaksi kontrak tawarruq, ketelusan operasi dapat ditingkatkan dengan nod (peserta transaksi) dalam rangkaian blok rantai dihubungkan ke dalam rangkaian tersebut dan dapat melihat transaksi jual beli yang berlaku secara masa sebenar. ${ }^{68}$

Kedua, risiko kesalahan urutan jual beli komoditi tawarruq dapat dikurangkan. Kesalahan urutan transaksi jual beli komoditi tawarruq sering berlaku dalam operasi perbankan Islam. ${ }^{69}$ Antara kesalahan urutan transaksi tawarruq ialah komoditi dijual kepada pelanggan sebelum bank membelinya daripada broker dan pemberian wang pembiayaan kepada pelanggan sebelum transaksi tawarruq disempurnakan. ${ }^{70}$ Kesalahan-kesalahan ini berpunca daripada manusia, iaitu staf bank yang tersalah atau

${ }_{66}$ Mohamed Cherif el Amri, Mustafa Omar Mohammed dan Ruslan Sabirzyanov, "The Potential of Smart Contracts for Murabahah Home Financing: Towards an Integrated Model," dalam Fintech, Digital Currency and the Future of Islamic Finance, (Palgrave Macmillan, Cham, 2021), 47-76.

67 Fabian Schar, "Decentralized Finance: On Blockchain- and Smart Contract-Based Financial Markets," Federal Reserve Bank of St. Louis Review 103, no. 20 (2021), 153-174.

68 Farrukh Habib, "Smart Contracts for Islamic Financial Transaction," dalam IFIKR DIGEST 11, (IFIKR, Kuala Lumpur, 2019), 10-15.

69 Mahbubi Ali dan Rusni Hassan, "Survey on Shari'ah Non-Compliant Events in Islamic Banks in the Practice of Tawarruq Financing in Malaysia," ISRA International Journal of Islamic Finance 12, no. 2 (2020), 151-169.

70 Hylmun Izhar, "Identifying Operational Risk Exposures in Islamic Banking," Kyoto Bulletin of Islamic Are Studies 3, no. 2 (2010), 17-53; Mahbubi Ali dan Rusni Hassan, Determinants of Shariah Non-Compliant Events Islamic Banks in Malaysia: With Special Reference to Tawarruq-Based Financing," al-Shajarah (2016), 217-242 ; BIMB, "Laporan Tahunan BIMB 2018", laman sesawang $B I M B$, dicapai pada 8 Ogos 2020, https://www.bankislam.com/wpcontent/uploads/BI_IAR18_Eng_FinancialStatement.pdf. 
tidak memasukkan perincian jumlah belian atau jualan komoditi secara tepat dalam sistem jual beli komoditi. ${ }^{71}$

Kesalahan berkait urutan transaksi tawarruq berpotensi dikurangkan dengan memanfaatkan teknologi kontrak pintar dan blok rantai sepenuhnya dalam operasi. Lazimnya setiap manusia mempunyai kecenderungan tertentu dalam setiap kelakuan, termasuklah semasa melaksanakan transaksi. Hal ini menyebabkan kepercayaan penuh dalam sesuatu transaksi sukar dicapai, terutama apabila peserta transaksi saling tidak mengenali antara satu sama lain. Maka, keadaan ini memerlukan kepada mekanisme khusus untuk memastikan kepercayaan dan tingkah laku yang betul dalam sesuatu transaksi tercapai. Sebaliknya para pemain teknologi berpandangan bahawa kod kontrak pintar berobjektif dan tidak mempunyai sebarang kecenderungan. Ia tidak berupaya menolak atau mengubah matlamat transaksi secara sendiri melainkan mematuhi kod terma yang telah ditulis. ${ }^{72}$

Tambahan lagi, pengesah transaksi yang melaksanakan protokol konsensus dalam rangkaian blok rantai dapat memastikan transaksi yang dilaksanakan oleh pengguna rangkaian tersebut selari dengan kod kontrak pintar. Setiap transaksi akan berjalan mengikut urutan yang telah ditetapkan dalam kod kontrak pintar. Sekiranya input transaksi yang dimasukkan ke dalam platform blok rantai tidak sah atau tidak selari dengan kod kontrak pintar, transaksi tersebut akan ditolak dan tidak dapat disahkan. Dengan itu, ekosistem kontrak pintar dan blok rantai dapat menguruskan sebarang kegagalan transaksi daripada berlaku atau transaksi yang tidak menepati urutan yang telah ditetapkan. ${ }^{73}$ Ia merupakan

71 Mahbubi Ali dan Rusni Hassan, "Survey on Shari'ah Non-Compliant Events in Islamic Banks in the Practice of Tawarruq Financing in Malaysia," ISRA International Journal of Islamic Finance 12, no. 2 (2020), 151-169.

72 Eliza MIK, "Smart Contracts: Terminology, Technical Limitations and Real World Complexity," Law, Innovation and Technology 9, no. 2 (2017) 269-300.

73 Khalid Alhamazan dan Ammar Alazani, Overview: Permissioned Blockchains-Ethereum Versus Hyperledger," Sci.Int.(Lahore) 31, no. 3 (2019), 513-515; Muhammad Faruq et al., "Application of Tawarruq in Islamic Banking in Malaysia: Towards Smart Tawarruq," IJMAR 7, no. 2 (2019), 100-113. 
satu ekosistem dan platform transaksi yang baik kepada kontrak tawarruq memandangkan transaksi tersebut mempunyai beberapa peringkat jual beli yang perlu dilaksanakan mengikut urutan yang betul bagi menghindar operasi tidak patuh Syariah. ${ }^{74}$

Tuntasnya, kontrak pintar dan blok rantai merupakan satu inovasi teknologi yang memberikan inisiatif baru dalam melaksanakan kontrak dan transaksi pembiayaan, khususnya pembiayaan berasaskan tawarruq. Penerapannya dalam penawaran produk berpotensi meningkatkan ketelusan transaksi di samping mengurangkan risiko kesalahan transaksi. Walau bagaimanapun, teknologi ini perlu diperhalusi lebih mendalam, khususnya berkaitan risiko yang terkait dengan operasinya.

\section{KESIMPULAN}

Kontrak pintar merupakan satu konsep kontrak yang dilaksanakan melalui rangkaian blok rantai. Ia beroperasi secara automatik, desentralisasi dan teredar (distributed). Peranannya sama dengan kontrak tradisional, iaitu membolehkan sesuatu transaksi dijalankan tanpa menjejaskan hak dan keselamatan pihak yang bertransaksi. Namun, perbezaannya dapat dilihat melalui operasinya. Kontrak tradisional lebih sinonim dengan proses yang melibatkan dokumen fizikal dan penglibatan manusia dalam operasi. Manakala kontrak pintar dilaksanakan dengan memanfaatkan rangkaian blok rantai dan kurang melibatkan campur tangan manusia dan dokumen fizikal. Teknologi kontrak pintar dan blok rantai berpotensi melaksanakan terma transaksi kontrak Syariah, antaranya kontrak tawarruq.

Penerapannya secara menyeluruh dalam transaksi kontrak Syariah bukan sekadar berupaya meningkatkan ketelusan operasi, malah turut berpotensi mengurangkan risiko kesalahan yang sering terjadi dalam operasi transaksi tradisional yang melibatkan campur tangan manusia. Walaupun begitu, perlu disedari bahawa transformasi ke arah operasi digital bakal mengubah landskap operasi dan juga landskap risiko yang sedia ada. Justeru, dalam

74 Muhammad Faruq et al., "Application of Tawarruq in Islamic Banking in Malaysia: Towards Smart Tawarruq," IJMAR 7, no. 2 (2019), 100-113. 
menghadapi dan mengikuti arus perkembangan teknologi yang pesat, institusi perbankan Islam dan para pengkaji perlu mengambil tindakan proaktif untuk memperhalusi risiko yang terkait dengan teknologi ini, khususnya risiko Syariah agar peralihan yang dilakukan tidak menjejaskan prestasi dan reputasi sistem perbankan Islam lalu memberikan tanggapan buruk kepada masyarakat terhadap industri ini.

\section{RUJUKAN}

Aishath Muneeza \& Zakariya Mustapha, "Blockchain and Its Shariah Compliant Structure," dalam Halal Cryptocurrency Management. Cham: Palgrave Macmillan, 2019.

Akram Laldin, "Fintech and Shariah Governance" laman sesawang Islamic Finance News, dicapai pada 20 Disember 2019, https://islmfintech.com/wp-content/uploads/2017/06/ Fintech-and-Shariah-governance-_-Islamic-Finance-News. pdf.

Alliance, Smart Contracts. Smart Contracts: 12 Use Cases for Business \& Beyond. Washingon D.C.: Chamber of Digital Commerce, 2016.

Az Azrinudin, Abdo Ali Abdullah dan Zamri Yusoff, "Overview of Blockchain Implementation on Islamic Finance: Saadiqin Experience," (makalah: 2018 Cyber Resilience Conference (CRC), tt, 2018), 1-2.

Bank Negara Malaysia, "Dokumen Polisi Tawarruq," laman sesawang Bank Negara Malaysia, dicapai pada 21 Mei 2021, https://www.bnm.gov.my/documents/20124/938039/ pd_reissuancetawarruq_dec2018.pdf/bcc4b359-381c5035-f9f0-3908faebb92a?t=1592249563244.

BIMB, "Laporan Tahunan BIMB 2018", laman sesawang BIMB, dicapai pada 8 Ogos 2020, https://www.bankislam.com/wpcontent/uploads/BI_IAR18_Eng_FinancialStatement.pdf.

BNM, "Financial Technology Regulatory Sandbox Framework," laman sesawang $B N M$, dicapai pada 2 Februari 2021, https://www.bnm.gov.my/index.php?ch=57\&pg=137\&ac= $533 \& b b=$ file. 
BNM, "Licensing Framework for Digital Banks," laman sesawang BNM, dicapai pada 2 Februari 2021 https://www.bnm.gov. my/documents/20124/938039/20201231_Licensing+Fram ework+for+Digital+Banks.pdf.

Bursa Malaysia, "Securities Borrowing And Lending: The Blockchain Path To Building Operational Efficiencies," laman sesawang BM, dicapai pada 7 Disember 2020, https://www.bursamalaysia.com/cn/about_ bursa/media centre/securities-borrowing-and-lending-the-blockchainpath-to- building- operational-efficiencies

Christian Catalini dan Joshua, "Some Simple Economics of the Blockchain," laman sesawang SSRN, dicapai pada 12 Julai 2020, https://papers.ssrn.com/sol3/papers.cfm?abstract $\mathrm{id}=2874598$.

Cointeghraph, "How blockchain technology works. Guide for beginners," laman sesawang Cointelegraph, dicapai pada 12 April 2021, https://cointelegraph.com/bitcoinfor-beginners/how-blockchain-technology-works-guidefor-beginners\#: : text $=\mathrm{A} \% 20 \mathrm{Block}$ chain $\% 20$ is $\% 20$ a\%20type,Each $\% 20$ transaction $\% 20$ generates $\% 20 \mathrm{a} \% 20$ hash.\&text $=$ Each $\% 20$ block $\% 20$ refers $\% 20$ to $\% 20$ the, $a \% 20$ copy $\% 20$ of $\% 20$ the $\% 20$ Blockchain.

Crowe, "Blockchain \& COVID-19: An Ongoing Conversation," laman sesawang Crowe, dicapai pada 14 April 2020, https:// www.crowe.com/sg/insights/blockchain-and-covid-19--an-ongoing-conversation.

Eliza MIK, "Smart Contracts: Terminology, Technical Limitations and Real World Complexity," Law, Innovation and Technology 9, no. 2 (2017) 269-300.

Ellida Fauziah et al., "Tawarruq as a Product for Financing within the Islamic Banking System: A Case Study of Malaysian Islamic Banking System," International Journal of Management and Applied Research 4, no. 1 (2017), 32-43.

Etherscan, "About Etherscan," laman sesawang Etherscan, dicapai pada 25 Julai 2021, https://etherscan.io/. 
Fabian Schar, "Decentralized Finance: On Blockchain- and Smart Contract-Based Financial Markets," Federal Reserve Bank of St. Louis Review 103, no. 20 (2021), 153-174.

Farhana dan Faridah, "Smart contract in Islamic Trade Finance," dalam Contemporary Management and Science Issues, (Singapore: Springer Publisher, 2019).

Farrukh Habib dan Moutaz Abojeib, " Realities and Innovation Challenges Potential Application of FinTech for Islamic Social Financing Institutions," (makalah: $13^{\text {th }}$ International Shariah Scholars Forum, Kuala Lumpur, 1-2 Oktober 2018), $1-19$.

Farrukh Habib, "Smart Contracts for Islamic Financial Transaction," dalam IFIKR DIGEST 11, (IFIKR, Kuala Lumpur, 2019), 10-15.

Finterra, "About us," laman sesawang Finterra, dicapai pada 5 Mei 2021, https://finterra.org/; Fintech News Malaysia.

HLIB, "Digital at the Core," laman sesawang HLIB, dicapai pada 2 Februari 2021https://www.hlisb.com.my/content/dam/ hlisb/my/docs/pdf/About-Us/Investor-Relations/AnnualQuarterly-Reports/2018/annual-report/hlisb-annualreport-2018.pdf.

HSBC, "HSBC Succesfully Pilots Malaysia's First Letter of Credit Transaction on The Blockchain," laman sesawang Fintechnews.my, dicapai pada 2 Februari 2021, Fintechhttps://fintechnews.my/21774/blockchain/hsbcpilots-blockchain-letter-of-credit-transaction-betweenmalaysia-and-singapore/.

Hussein Elasrag, "Blockchains for Islamic Finance: Obstacles \& Challenges," MPRA, (2019), 1-32.

Hylmun Izhar, "Identifying Operational Risk Exposures in Islamic Banking," Kyoto Bulletin of Islamic Are Studies 3, no. 2 (2010), 17-53.

Ilinka Antova dan Tahar Tayachi, "Blockchain and smart contracts: A Risk Manegement Tool for Islamic Finance," Journal of Islamic Financial Studies 5, no. 1 (2019), 29-42. 
Jessica Chew Cheng Lian, "Deputy Governor's Opening Address at the Asian Banker Digital Finance Convention 2018," laman sesawang $B N M$, dicapai pada 2 Februari 2021, https:// www.bnm.gov.my/-/deputy-governor-s-opening-addressat-the-asian-banker-digital-finance-convention-2018.

Khalid Alhamazan dan Ammar Alazani, Overview: Permissioned Blockchains-Ethereum Versus Hyperledger," Sci.Int. (Lahore) 31, no. 3 (2019), 513-515.

Lum Kar Hoe, "Covid-19: Opportunities and Challenges For Digital Bank," laman sesawang $P W C$, dicapai pada 18 April 2020, https://www.pwc.com/my/en/perspective/digital/200408pwc-blog-covid-19-opportunities-challenges-digital-banks. html.

Magda Ismail dan Aishath Muneeza, "Integrating Waqf Crowdfunding into The Blockchain," dalam Fintech in Islamic Finance: Theory and Practise (New York: Routledge, 2019).

Mahbubi Ali dan Rusni Hassan, Determinants of Shariah NonCompliant Events Islamic Banks in Malaysia: With Special Reference to Tawarruq-Based Financing," Al-Shajarah, (2016), 217-242.

Mahbubi Ali dan Rusni Hassan, "Survey on Shari'ah NonCompliant Events in Islamic Banks in the Practice of Tawarruq Financing in Malaysia," ISRA International Journal of Islamic Finance 12, no. 2 (2020), 151-169.

Marco Tieman dan Mohd Ridzuan, "Leveraging Blockchain Technology for Halal Supply Chains," Islam and Civilisation Renewal 8, no. 40 (2017), 547-550.

Mark Giancaspro, “ Is A 'Smart Contract Really A Smart Idea? Insight From A Legal Perspective," Computer Law And Security Review (2017), 1-11.

Mohamed Cherif el Amri, Mustafa Omar Mohammed dan Ruslan Sabirzyanov, "The Potential of Smart Contracts for Murabahah Home Financing: Towards an Integrated Model," dalam Fintech, Digital Currency and the Future of Islamic Finance, (Palgrave Macmillan, Cham, 2021), 4776. 
Mohammad Abdeen et al., Employing Takaful Islamic Banking Through State of The Art Blockchain: A Case Study," IJACSA 10, no. 12 (2019), 648-653.

Mohd Izuwan Mahyudin dan Azizi Che Seman, "The Application of Bay'al-Tawarruq in Islamic Banking Institutions in Malaysia," dalam New Developments in Islamic Economics. Bingley: Emerald Publishing Limited, 2018, 169-179.

Mohd Izuwan, "Aplikasi Tawarruq dalam Sistem Perbankan Islam: Kajian di Bank Muamalat Malaysia Berhad." Tesis sarjana, Universiti Malaya, Kuala Lumpur, 2015.

Muhammad Faruq et al., "Application of Tawarruq in Islamic Banking in Malaysia: Towards Smart Tawarruq," IJMAR 7, no. 2 (2019), 100-113.

Nick Szabo, "Formalizing and Securing relationships on Public Networks," Uic Journals 2(9), (1997), https://journals.uic. edu/ojs/index.php/fm/article/view/548/469\#Conclusion.

Nicola, Massimo dan Tiziana, "A Survey of Attacks on Ethereum Smart Contracts," dalam International Conference on Principles of Security and Trust. Springer: Berlin, Heidelberg, 2017.

Nor Razinah, "Smart Contract in Blockchain: An Exploration of Legal Framework in Malaysia," Intellectual Discourse 27, no. 2 (2019), 595-617.

Nur Husna Zakaria, Sherin Kunhibava, Md. Ershadul Karim, Abu Bakar Munir dan Raphael Kok, Thing Ming Sen dan Ridoan Karim, "Malaysian Blockchain Regulatory Report," https:// law.um.edu.my/Research-UMCORS/RegTech/UM\%20 $\% 20$ Malaysian $\% 20$ Blockchain $\% 20$ Regulatory $\% 20$ Research\%20Report.pdf.

Peter Eza, Tochukwu dan Chinedu, "A Triplicate Smart Contract Model using Blockchain Technology," Circulation in Computer Science-Special Issue (2017), 1-10.

Pieter Harte dan Mark Van Staalduinen, Truffle Test for FreeReplaying Ethereum Smart Cotnracts for Transparency, ArXiv, (2019), 1-20. 
Richard-Marc, Berthe Lambert dan Nida Khan, "Blockchain Technology-Arsenal for a Shariah-Compliant Financial Ecosystem," Journal of Business and Economics (2017), $1-11$.

Romulo Luciano, "The Hazards of Misusing the Smart Contract: An AHP Approach to Its Risk," JIS 10, no. 1 (2019).

Shahbaz Alam dan Hina Noor, "Mined and Non-Mined Crypto Currencies: A Critical Analysis from Shariah Perspective," International Journal of Innovative Science and Research Technology 5, no, 3 (2020), 429-437.

Siti Rohaya et al., "Artificial Intelligence, Smart contract and Islamic Finance," Asian Social Journal 14, no. 2 (2018), 145-154.

Suruchi Mann, Raj Shkhar dan Anulipt Chandan, "Blockchain Technology for Supply Chain Traceability, Transparency and Data Provenance," (makalah: 2018 International Conference on Blockchain Technology and Application, Xian, China, 2018), 22-26.

The Star, "Bank Islam to Offer Digital Products," laman sesawang The Star, dicapai pada 7 Disember 2020, https://www. thestar.com.my/business/business-news/2020/02/18/bankislam-to-offer-digital-products.

Tianyu Feng, Xiao Yu, Yueting Chai dan Yi Liu, "Smart Contract Model For Complex Reality Transaction," International Journal of Crowd Science 3, no. 2 (2019), 194-197. 